\title{
Konlk PERILAKU PENGUNJUNG DALAM MENULIS BUKU TAMU PAMERAN
}

Volume 2, Nomor 2

Juli 2020,

(95-102)

\author{
Ripase Nostanta Br. Purba \\ Pengkajian Seni Lukis \\ Program Pascasarjana Institut Seni Indonesia, Yogyakarta \\ e-mail : Kimripa17@gmail.com
}

\begin{abstract}
ABSTRAK
Pameran adalah sarana untuk menunjukkan hasil karya seni untuk diperlihatkan kepada orang lain. Pameran bisa berupa karya seni seperti lukisan, foto, patung maupun barang antik. Dalam memulai suatu pameran banyak persiapan yang harus dilakukan salah satunya adalah buku tamu. Buku tamu biasanya berada di meja tamu dekat pintu ruang pameran atau tergantung akses masuk lokasi pameran sendiri. Buku pameran sendiri terdiri dari beberapa format tulisan yang umum seperti, nomor, nama, alamat, nomor handphone, alamat e-mail dan tanda tangan. Namun pengunjung sering tidak menulis apa yang seharusnya ditulis pada buku tersebut, bahkan ada yang hanya menulis nama saja dan tidak mengisi kolom lainnya, ada beberapa kolom yang dikosongkan pada bagian tertentu. Karena hal tersebut penulis merasa perlu untuk mengamati perilaku seseorang dalam menulis buku tamu pada pameran, apakah ada tujuan seseorang tersebut menulis nama atau alamat dengan tidak sesuai dengan yang seharusnya, apakah faktor seseorang tersebut menulis hal seperti itu, perilaku yang bagaimana yang ditunjukkan pengunjung pada tulisannya dibuku tamu. Metode yang digunakan pada penelitian ini adalah pengamatan, dengan pemilihan data hanya pada pembukaan pameran dengan durasi 40 sampai 2 jam.
\end{abstract}

Kata Kunci : buku tamu, karya seni, lukisan, pameran, perilaku pengunjung.

\section{ABSTRACT}

Exhibition is a means to show the work of art to be shown to others. The exhibition can be in the form of works of art such as paintings, photographs, sculptures and antiques. In starting an exhibition, many preparations must be made, one of which is a guest book. Guest books are usually located on the guest table near the door of the exhibition hall or depending on access to the exhibition location itself. The exhibition book itself consists of several common writing formats such as, number, name, address, mobile number, e-mail address and signature. But visitors often do not write what should be written in the book, some even just write the name and do not fill in other columns, there are some columns that are left blank in certain sections. Because of this I feel the need to observe someone's behavior in writing a guest book at an exhibition, is there a person's purpose to write a name or address that is not what they should be? what is the factor for someone to write such a thing? what behavior does the visitor show in his guest book? the method used is observation, with data selection only at the opening of the exhibition with a duration of 40 to 2 hours.

Keywords: guest book, artwork, painting, exhibition, visitor behavior

\section{PENDAHULUAN}

Pameran adalah sarana untuk menunjukkan hasil karya seni untuk diperlihatkan kepada orang lain. Pameran bisa berupa karya seni, barang antik, maupun berupa foto - foto. Dalam memulai suatu pameran banyak persiapan yang harus dilakukan seperti menyusun kepanitiaan, agenda, proposal, dan hal yang tidak luput adalah buku tamu, hingga tiba saat hari pembukaan. Buku tamu merupakan salah satu bagian kecil dari persiapan pameran namun penting, buku tamu biasanya berada di meja tamu dan biasanya berada di dekat pintu ruang pameran, tergantung akses masuk lokasi pameran sendiri. Buku pameran sendiri terdiri dari beberapa format tulisan yang umum seperti, nomor, nama, alamat, nomor handphone, alamat $e$-mail dan tanda tangan. Namun ada pula yang memiliki format berbeda, tergantung pada jenis buku tamu yang dipakai. Ada buku tamu yang umum diperjual belikan dengan format isian berupa nomor, nama, alamat dan tanda tangan, ada pula buku tamu yang menulis format nomor, nama, alamat,no handphone/e-mail dan tanda tangan. selain kedua jenis itu, ada pula buku tamu hasil ketikan sendiri yaitu dengan ciri-ciri tercantum kop berupa judul pameran, namun format isian ada yang berbeda dengan buku tamu yang diperjual-belikan, perbedaanya berada pada kolom nomor handphone dan e-mail, tergantung kebutuhan informasi panitia 
sendiri. Namun baik buku tamu yang diperjualbelikan secara umum, maupun yang diprint sendiri, pengunjung tidak menulis apa yang seharusnya ditulis pada buku tersebut, bahkan ada yang hanya menulis nama saja dan tidak mengisi kolom lainnya, ada beberapa kolom yang dikosongkan pada bagian tertentu. Kasus lain terlihat seperti dalam penulisan alamat, banyak pengunjung yang menulis dengan alamat asli seperti Sewon ada pula yang menulisnya dengan Sewonderland. Dalam hal ini penulis merasa perlu untuk mengamati perilaku seseorang dalam menulis buku tamu pada pameran, dengan rumusan masalah seperti: apakah ada tujuan seseorang tersebut menulis nama atau alamat dengan tidak sesuai dengan yang seharusnya ? apakah faktor seseorang tersebut menulis hal seperti itu? perilaku yang bagaimana yang ditunjukkan pengunjung pada tulisannya dibuku tamu?

\section{METODE PENELITIAN}

Dalam mengangkat tentang perilaku pengunjung pameran dalam menulis buku tamu, penulis mendatangi tujuh pameran dengan jenis pameran yang berbeda pula, mulai dari pameran seni rupa, pameran barang-barang lawasan dan pameran foto. Berbeda jenis pameran maka berbeda pula para pengunjung yang menghadirinya, tergantung pada seniman dan karyanya, misalnya yang berpameran adalah tokoh masyarakat atau anggota suatu sanggar maka yang banyak berkunjung adalah orang tua, anggota sanggar dan anak muda sangatlah sedikit, begitu pula sebaliknya, apabila yang berpameran adalah anak muda ataupun mahasiswa/seorang alumni suatu kampus, maka kebanyakan pengunjung yang datang adalah anak muda dan jumlah orang tua yang datang sangat sedikit pula. Saat melakukan penelitian, penulis mengamati dengan durasi yang berbeda-beda diketujuh tempat pameran, durasi paling singkat adalah 40 menit dan yang paling lama adalah 2 jam 30 menit.

\section{a. Pemilihan Data (Mencuplik Data)}

Dalam mencuplik data dari tujuh pengamatan pada pameran, 6 pameran penulis datangi saat pembukaan dan 1 pameran pada hari kedua setelah pembukaan, pameran tersebut terdiri dari: pameran barang antik slompret jogja, pameran seni rupa persepsi-persepsi kematian, pameran lukisan mojo, pameran lukisan abstrak terus tumbuh di dalam rongga, pameran kriya matra, pameran foto tokoh \& seni budaya jogja Khocil Birawa, pameran perupa muda \#3 ringroad. Alasan penulis mengambil waktu pengamatan pada saat pembukaan yaitu para pengunjung sangat ramai dan penulis bisa mengamati dengan cukup efektif dalam waktu satu jam sambil menunggu pameran dibuka. Namun, hal berbeda terlihat saat penulis datang dihari kedua pameran, pengunjung sangat sedikit, walau menghabiskan waktu 2 jam 30 menit. Pengamatan penulis ini termasuk pada tipikal.

\section{b. Teknik Pengumpulan Data}

Cara penulis mengumpulkan data adalah dengan mengamati para pengunjung dan menjadi penjaga buku tamu, lebih lanjut penulis mendokumentasikan buku tamu tersebut dan mengamati kembali tulisan-tulisan mereka. Hal-hal yang diamati yaitu bagaimana pengunjung mengisi kolom yang sudah ditentukan oleh pihak panitia. Penulis menggunakan panduan pengamatan yang terdiri dari empat bagian yaitu:

1) Cara pengamatan terdiri dari ;

- Berapa kali pengamatan

- Durasi pengamatan

- Posisi pegamat dalam mengamati

2) Menuliskan secara rinci tentang pameran, terdiri dari ;

- nama pameran

- jenis pameran

- seniman yang berpaameran

- tempat pameran

- tanggal pameran

- tanggal pengamatan

- lokasi pameran

- waktu pameran

- jam pengamatan

- posisi tempat penulisan buku tamu

3) Panduan Buku tamu, terdiri dari;

- apa saja yang harus dicantumkan oleh pengunjung

4) Perilaku Pengunjung, Terdiri dari;

- apakah pengunjung mengisi secara lengkap panduan dari kolom atau tidak

- dari kolom yang tercantum apakah ada bagian yang dilewatkan/tidak tertulis

- apakah pengunjung menulis dengan lengkap atau hanya dengan singkat ?

- apakah pengunjung yang datang berkelompok atau berpasangan ? apabila berpasangan apakah mereka menulis dengan mewakilkan salah satu nama atau tidak?

- apakah ada pengunjung yang memasuki ruang pameran tanpa menulis buku tamu?

dari panduan di atas penulis mendapatkan 7 catatan pengamatan.

Akses untuk memasuki tempat pameran merupakan salah satu kendala yang terkadang dihadapi oleh pengamat, begitu pula yang penulis hadapi dari beberapa pameran yang telah 
dikunjungi. Beberapa dari pihak panitia meminta surat izin penelitian walau hanya untuk menjadi penjaga buku tamu, namun hal ini masih mampu penulis selesaikan dengan berbicara langsung dengan ketua panitia atau kepala galeri.

Alat pengamatan yang penulis gunakan adalah kamera handphone, pena dan buku tulis. Penggunaan buku dan pena sendiri penulis gunakan saat penulis menjaga sambil mencatat hal-hal yang terjadi. Lalu setelah pengunjung terlihat makin sedikit dan penulis merasa pengamatan sudah cukup, tahap selanjutnya adalah mendokumentasikan buku tamu tersebut dengan kamera handpone di mulai dari halaman pertama hingga terakhir dari buku tamu. Begitu seterusnya dari pengamatan satu hingga ketujuh. Saat mengamati, penulis menemukan beberapa hal yang tidak seperti biasanya, contohnya dalam menulis nama kebanyakan pengunjung hanya menulis satu kata dari namanya, lalu dibagian alamat mereka banyak menuliskan asal kampus mereka misalnya 'Pascasarjana ISI, UNY' ada juga yang menulis nama kota. Selain itu ada yang menulis alamat rumah dengan alamat $e$-mail. Hal unik lainnya juga penulis temui seperti menulis alamat dengan kata 'Dunia, Kontrakane Tuyul dll'. Setiap pengunjung yang datang pasti menandatangani buku tamu tersebut, terlihat dari tidak ada tanda tangan yang kosong. Kolom yang paling sering kosong dari yang penulis amati di beberapa tempat pameran yaitu penomoran atau nomor urut dan juga alamat. Penomoran saat lembar pertama masih dibantu tulis oleh penjaga buku tamu, namun tidak untuk lembar selanjutnya. Selain itu dipameran lukisan Mojo, fenomena lain terlihat seperti penulisan alamat yang ditulis hanya berupa emoticon hati (love). Pada Pameran lukisan Rongga, terdapat kejadian seperti pengunjung yang datang tidak menulis alamat $e$-mail dan tanda tangan, dan ditulis dengan sangat cepat, melihat karya pameran hanya sebentar lalu pergi. Namun hal ini tidak berlaku pada semua pengunjung, pengunjung lain terlihat serius dalam menulis buku tamu tersebut. Pada pengisian kolom alamat $e$-mail dan nomor handphone pada pameran Rongga, pengunjung memilih lebih menulis alamat e-mail daripada nomor hp, namun ada juga yang menggunakan tanda " -|l-" yang dapat diartikan 'sama dengan yang diatas'.

Penulis mempunyai sembilan lembar catatan pengamatan, dari total 9 lembar tersebut penulis melakukan pengkodean. Pengkodean yang penulis lakukan hanya pada informasi yang penulis anggap berguna. Dari total tujuh pengamatan yang penulis lakukan, terdapat lebih dari 20 kode yang terdiri dari; pengunjung, pameran, buku tamu, alamat, nama pengunjung, meminta bantuan informasi, meja tamu, format isi kolom, hal unik, kolom kosong, kelompok usia, tugas penjaga, daerah, memastikan menunggu pembukaan, melompati kolom, lembaga pendidikan, ijin, jenis galeri. Dari ke dua puluh kode tersebut penulis mencari kesamaan beberapa kode dan di press menjadi enam kode saja yaitu identitas, kegiatan, penulisan buku tamu, penjaga buku tamu, akses, dan galeri. Dan dari enam kode tersebut penulis melakukan pengkodean tahap ke tiga yaitu menjadi pengunjung, tempat pameran, dan pameran.

Di beberapa tempat pameran ada pula yang menggunakan buku tamu digital yaitu aplikasi google form, Namun kelemahan penggunaan google form untuk penelitian ini adalah penulis tidak dapat mengetahui data pengunjung begitupun perilakunya apakah mereka menulis sesuai dengan benar atau tidak, karena sistem google form membuat pengunjung wajib mengisi semua kolom isian agar bisa submit.

\section{HASIL DAN PEMBAHASAN}

Buku tamu memiliki peranan penting tersendiri dalam menyimpan data pengunjung dan untuk mengetahui berapa banyak minat pengunjung atas suatu pameran, hal ini juga sesuai dengan pendapat dari Moskwa (2015:208) "The term guest book is used in this research to refer to a visitor log book (or ledger) commonly supplied at tourism attractions or accommodation providers for people to record their names, place of residence, dates of travel, and any comments or feedback about their experience", berikut adalah hasil temuan pengamatan penulis:

\section{a. Penomoran}

Dari tujuh pengamatan, pengunjung pameran tidak akan menulis nomor apabila tidak ada panduan dari nomor pertama, misalnya apabila lembar kedua halaman seharusnya nomor 13 dan pengunjung tidak menulis kelanjutannya maka sampai lembar selanjutnya tidak akan ada yang menulis nomor. Berikut adalah perbandingan antara buku tamu yang dipandu dengan penomoran oleh penjaga buku tamu dan yang tidak:

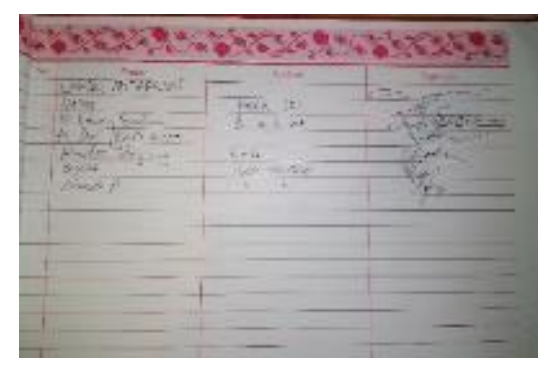

Gambar 1. Buku tamu pameran foto tokoh \& seni budaya jogja khocil birawa 


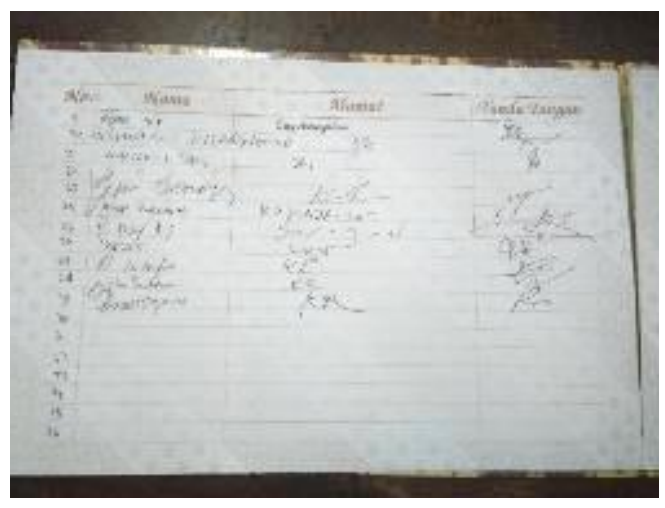

Gambar 2. Buku tamu pameran pameran seni rupa persepsi-persepsi kematian

\section{b. Nama}

Hasil penelitian terhadap 6 buku pameran, pada bagian nama para anak muda biasanya hanya menulis nama panggilan saja atau akronim, hal ini juga ada dijelaskan pada penelitian Noy (2008: 193), "the former acronym stands for besahadei deshmaya or besai'ata deshmaya ("with God's help" in Aramaic), and the latter for be'ezrat hashem ("with God's help" in Hebrew)", Hasil pengamatan yang ia lakukan pada The AHNMS Museum Jerussalem, dari hasil pengamatannya Noy membuat catatan tentang akronim yang terjadi saat itu dalam menulis buku tamu. Namun berbeda terjadi apabila pengunjungnya orang tua maka mereka akan menulis nama mereka dengan lengkap

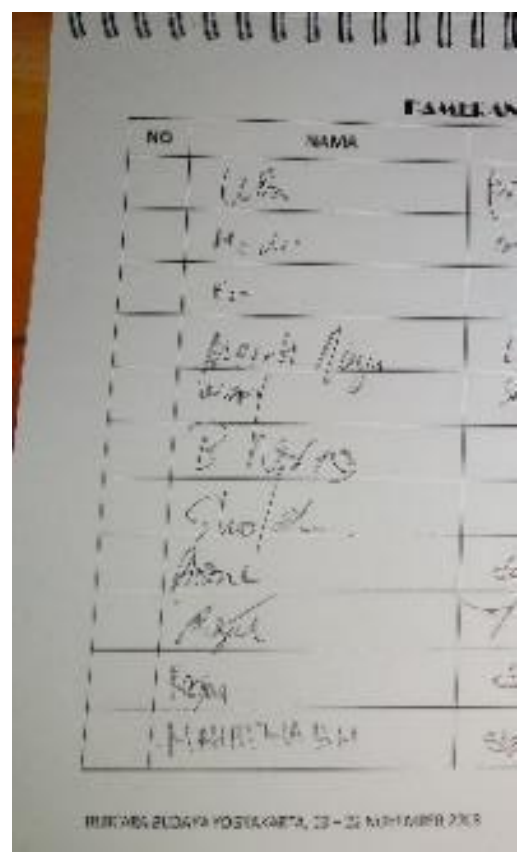

Gambar 3. Buku tamu pameran slompret

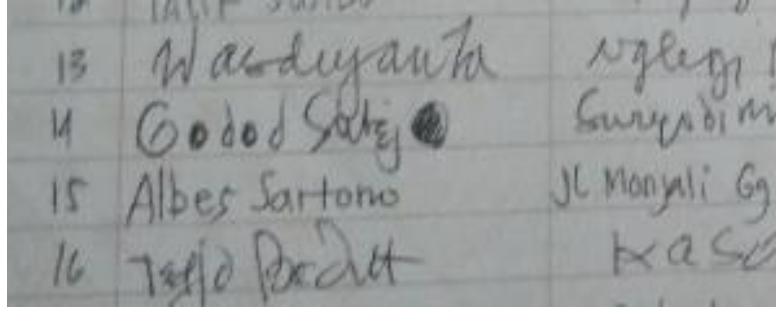

Gambar 4. Buku tamu pameran foto tokoh \& seni budaya jogja khocil birawa

c. Alamat

Alamat yang digunakan oleh pengunjung hanyalah nama daerah saja sepert 'Bantul, Sleman, Kasihan' tidak menuliskan secara detail dan lengkap, namun ada pula yang menulis alamat dengan becandaan seperti 'Dunia, Kontrakane Tuyul dll'. Sedangkan berbeda dengan orang tua yang menulis alamat pada buku tamu, contohnya salah satu pengunjung yaitu seorang bapak menulis alamat dengan lengkap seperti 'Nyutran, Mj II/Ibyo', tulisan bapak tersebut memang kurang jelas tapi apabila diamati sepertinya beliau ingin menulis kecamatan Mantrijeron. Pada bagian alamat, banyak pengunjung menggunakan nama daerah seperti "Sewon, Taman Siswa, Nitikan, Prawirotaman" namun ada juga yang menulis alamat dengan emotikon hati (love sign) maupun nama sekolah dan kampus seperti 'SMSR, ISI YK', selain itu ada juga yang menulis 'sewonderland, umah mepi, desa dll'.

Namun hal berbeda terjadi pada pameran foto lawasan yang dikunjungi oleh orang tua, mereka menulis kolom alamat dengan alamat kerja mereka misalnya 'Krjogja.com, TVRI, Adi TV, SCTV', pengunjung yang membuat alamat seperti itu kemungkinan adalah rekan kerja dari seniman yang berpameran, karena setelah ditelusuri lebih lanjut seniman yang berpameran berprofesi sebagai wartawan, namun ada juga yang menulis alamat dengan nama kecamatannya saja.

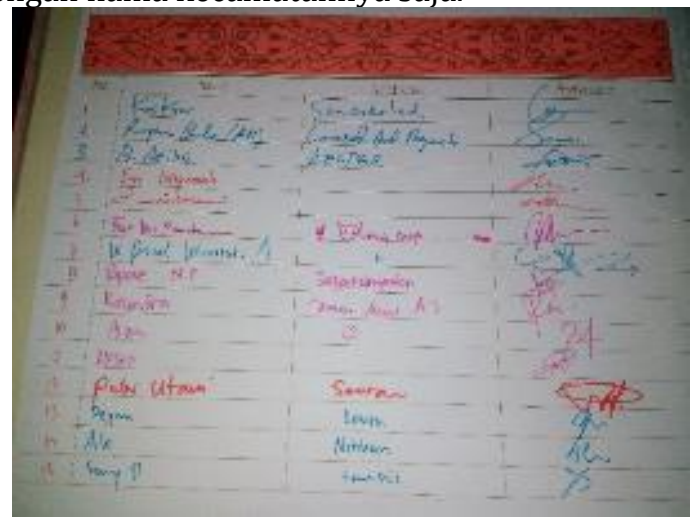

Gambar 5. Buku tamu pameran mojo 


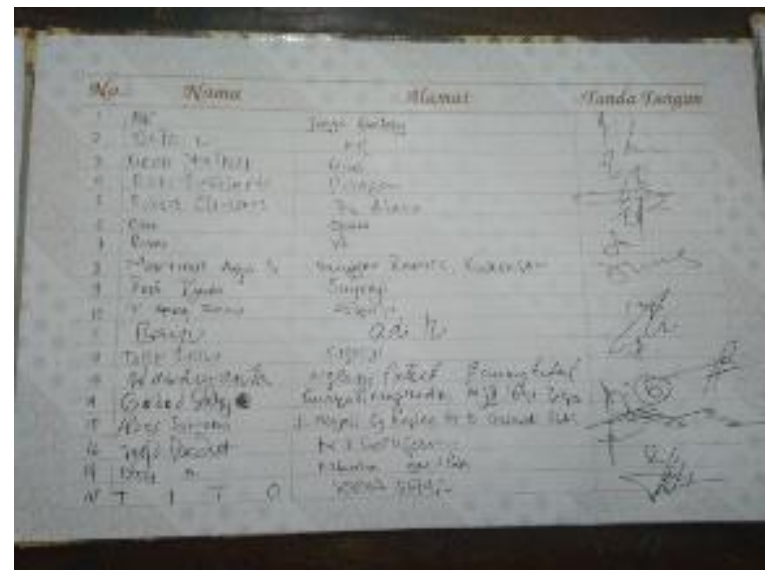

Gambar 6. Buku tamu pameran foto tokoh \& seni budaya jogja khocil birawa

\section{d. Nomor handphone atau e-mail}

Pada kolom nomor handphone atau e-mail hanya beberapa buku tamu saja yang menyediakan format seperti ini, seperti buku tamu yang merupakan buatan panitia sendiri. Dari beberapa buku tamu, para pengunjung lebih fokus menulis alamat e-mail dari pada nomor handphone, dan beberapa ada juga yang menggunakan tanda " -|I-“ yang dapat diartikan sama dengan yang di atas. Selain itu, ada juga yang menulis dibagian $e$-mail dengan nama kampus seperti 'ISI PP' mungkin yang dimaksudnya Institut Seni Indonesia Padang Panjang, namun dari tujuh pengamatan penulisannya ada tiga buku yang mencantumkan nomor handphone atau e-mail, jadi dapat disimpulkan pengunjung pameran apabila diberi opsi menulis nomor handphone atau $e$-mail, mereka akan lebih mengutamakan menulis alamat $e$-mail.

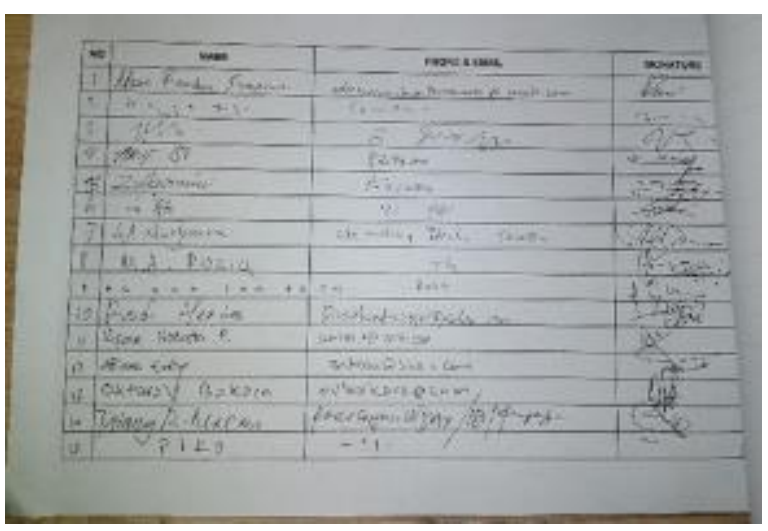

Gambar 7. Pameran lukisan abstrak terus tumbuh di dalam rongga

e. Tanda Tangan

Dari tujuh pengamatan, penulis melihat hal yang paling banyak di isi dalam buku tamu adalah nama dan tanda tangan,dan hampir pada semua buku tamu pasti kolom tanda-tangan akan diisi.

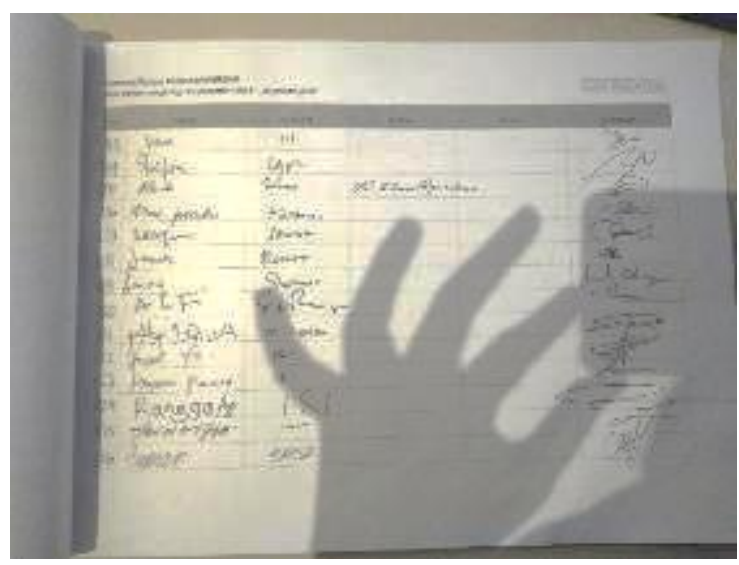

Gambar 8. Buku tamu pameran perupa muda \#3 ringroad.

\section{f. Jenis Buku Tamu}

Buku tamu sendiri terdiri dari dari dua jenis yaitu yang diperjual-belikan secara umum dengan format isian nomor, nama, alamat dan tanda-tangan dan hasil ketikan dari panitia dengan format tertentu dengan data informasi yang dibutuhkan oleh mereka, salah satunya adalah buku tamu formal dari lembaga pemerintah. Sebenarnya banyak kekurangan dari buku tamu jenis manual karena data tidak bisa disimpan dalam jangka waktu lama karena kertas atau tinta yang tidak bisa bertahan lama, maupun keamanan data, sama seperti menurut franklin (2011:252), "Books and pens could be stolen, damaged or run out of space or ink". Namun ada juga buku tamu formal dari pemerintahan yaitu dengan format kop surat dinas diatasnya yang wajib diisi oleh penjaga buku tamu, dengan format isian yang berupa nama, alamat dan tanda tangan dengan susunan selang-seling dan diakhir kolom terdapat tanda-tangan pejabat yang bertanggung jawab pada acara tersebut. Lalu ada pula jenis buku tamu yang diketik sendiri oleh panitia pameran yang berisi format nomor, nama, alamat, nomor handphone, alamat e-mail dan tanda tangan. Dari kedua jenis buku tamu tersebut banyak yang masih menggunakan buku tamu yang umum dan biasa diperjualbelikan, namun untuk lembaga pemerintahan, mereka menggunakan yang memakai kop surat pemerintah dan untuk buku tamu hasil ketikan sendiri biasanya dipakai untuk pameran bersama atau pameran tunggal pada galeri tertentu. 

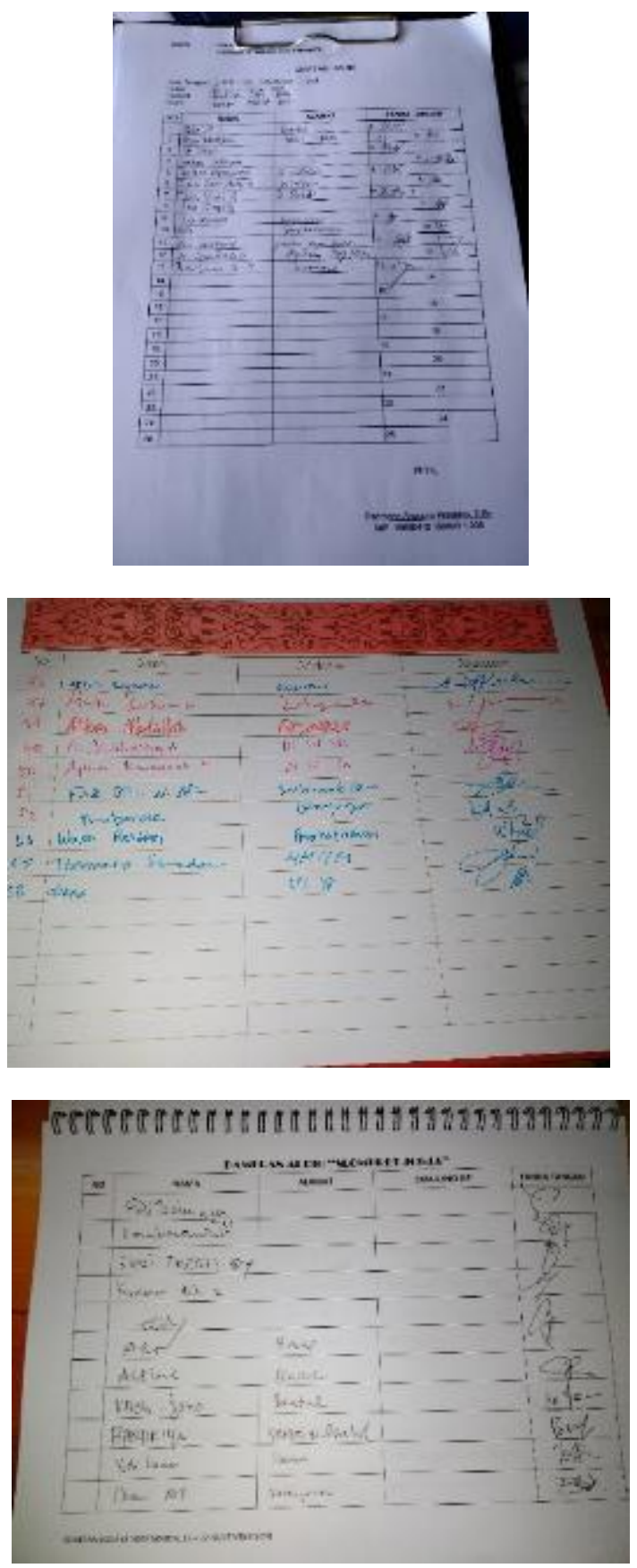

Gambar 9. Perbandingan buku tamu hasil ketikan official pameran, buku tamu dari pemerintahan dan buku tamu yang umum diperjualbelikan.

\section{g. Pengunjung Pameran}

Pengunjung pameran menentukan apa yang mereka isi, dalam hal ini penulis membagi menjadi dua bagian yaitu pengunjung yang merupakan siswa/ mahasiswa/ umum (anak muda) dan pengunjung umum yang biasanya orang tua. Pengunjung pameran anak muda biasanya mengisi buku tamu dengan sesuka hati tanpa memikirkan apa yang ditulis sesuai atau tidak dengan perintah pengisian kolom, bahkan bisa juga tidak mengisi salah satu kolom. Namun berbeda dengan pengunjung umum terutama orang tua yang mana mereka mengisi lebih lengkap dan menyesuaikan dengan perintah isi buku tamu.

\section{h. Jenis pameran}

Jenis pameran sangat menentukan pengunjung pameran. Apabila yang melakukan pameran adalah mahasiswa atau alumni kampus maka yang menjadi pengunjung lebih banyak adalah pelajar (anak muda) dan kebanyakan dari mereka mengisi buku tamu secara suka-suka, asalasalan dan tidak serius mengisinya. Menurut Clark dan Dugdale (2009: 38) "Young people are ambivalent in their attitudes towards writing. They agree with statements such as that writing is more fun when they can choose the topics, that it is easier to read than to write and that their writing improves with practice". Pada penelitian Christina Clark and George Dugdale juga membahas permasasalahan dibeberapa tempat pengamatan adalah saat anak muda yang menulis buku tamu dengan asal-asalan dalam hal nama, alamat.

\section{KESIMPULAN}

Dalam mengamati perilaku seseorang dalam mengisi buku tamu, penulis telah mengamati tujuh buku tamu dari tujuh tempat pameran berbeda. Apakah ada tujuan seseorang tersebut menulis nama atau alamat dengan tidak sesuai dengan data yang seharusnya? maka jawabannya adalah mereka tidak memiliki tujuan tertentu hanya saja seperti penulisan "sewonderland" merupakan hal biasa dikalangan anak muda yang tinggal di daerah sewon untuk menamai daerahnya. Apakah faktor seseorang tersebut menulis hal seperti itu ? faktor seseorang dalam menulis alamat dengan data yang sebenarnya atau tidak lengkap adalah masalah privasi, beberapa pengunjung tidak mau diketahui tentang hal-hal yang bersifat pribadi. Perilaku yang bagaimana yang ditunjukkan pengunjung pada tulisannya dibuku tamu ? dari beberapa buku tamu, para pengunjung lebih memilih tidak menulis alamat dengan lengkap dan menulisnya secara asal, tidak menulis nomor handphone maupun e-mail.

Hasil yang penulis temukan adalah dua tipe pengunjung, pengunjung anak muda dan pengunjung orang tua, pada pameran barangbarang antik atau pameran foto lawasan yang senimannya adalah orang tua akan lebih banyak dihadiri oleh pengunjung yang orang tua pula, begitupun dengan pameran lukisan yang senimannya adalah pelajar, mahasiswa atau alumni suatu kampus kebanyakan pengunjung yang datang adalah anak muda ataupun teman-temannya yang seumuran dengan senimannya pula. Jenis pameran dan seniman yang berpameran berpengaruh 
terhadap tamu yang hadir, dan kehadiran tamu berpengaruh pada buku tamu yang ditulis oleh mereka. Buku tamu yang diisi oleh anak muda lebih terlihat fleksibel, mereka tidak begitu mengubris perintah kolom, mereka lebih sesuka hati dalam menulis isi dari buku tamu, tidak menuliskan alamat dan e-mail dengan data yang sesungguhnya, melainkan diisi dengan kata-kata seperti 'dunia, kontrakane tuyul dll' yang terkesan candaan atau hanya dengan emotikon tertentu. Namun buku tamu yang diisi oleh para orang tua terlihat lebih tersusun rapi, mereka mengisi setiap perintah pengisian kolom. Jadi, jenis pameran dan seniman yang berpameran berpengaruh pada pengunjung serta pengisian buku tamu.

Saran penulis terhadap peneliti lain yang ingin melakukan penelitian atau mengembangkan penelitian dengan topik yang sama yaitu agar fokus kepada buku tamu pada museum yang mungkin lebih kompleks . seperti menurut Vanderbyl (2017: 113) "Visitor books are a rich source for examining the nexus of mission tourism, imperial intimacies and emotion." Banyak hal yang akan ditemukan termasuk hal-hal lain yang belum diteliti oleh penulis sendiri, seperti emosi dari pengunjung itu saat menulis buku tamu.

\section{DAFTAR PUSTAKA}

Clark, Christina \& George Dugdale. (2009). "Young People's Writing: Attitudes, behaviour and the role of technology". London: National Literacy Trust.

Franklin, NatalieR. (2011). "Visitor Books In The Management 0 Rock Art Sites: An Evaluation Using Carnarvon Gorge As A Test Case". Rock Art Research, Vol 28, No. 2, Pp. 251-264.

Moskwa, Emily 2015). "Reflections On Judgment: An Analysis of Tourists' Contributions To Guest Books". Tourism Review International, Vol. 19, Pp. 207- 223

Noy, Chaim. (2008). "Mediation Materialized: The Semiotics of a Visitor Book at an Israeli Commemoration Site". Critical Studies in Media Communication Vol. 25, No. 2, pp. 175-195

Vanderbyl, Nikita. (2017). “The Happiest Time of My Life ...': Emotive Visitor Books And Early Mission Tourism To Victoria's Aboriginal Reserves". Aboriginal History Vol 41, Pp 95 120 
Ripase Nostanta Br. Purba / IKONIK : Jurnal Seni dan Desain, Vol. 2, No.2, Juli 2020, 95-102

(halaman ini sengaja dikosongkan) 